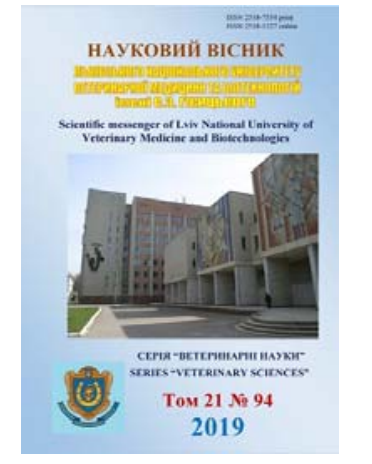

Науковий вісник Дьвівського національного університету ветеринарної медицини та біотехнологій імені С.3. Гжицького.

\author{
Серія: Ветеринарні науки
}

Scientific Messenger of Lviv National University of Veterinary Medicine and Biotechnologies. Series: Veterinary sciences

\title{
Epizootic features of the manifestation of clostridiosis and means of specific prophylaxis of animals in Ltd n.a. Volovikova Hoshchansk districk, Rivne region
}

\author{
N.D. Levkivska, D.M. Levkivsky, B.V. Gutyj
}

Stepan Gzhytskyi National University of Veterinary Medicine and Biotechnologies Lviv, Ukraine

Article info

Received 18.04.2019

Received in revised form 20.05.2019

Accepted 21.05.2019

Stepan Gzhytskyi National University of Veterinary Medicine and Biotechnologies Lviv, Pekarska str., 50, Lviv, Ukraine. Tel.: +38-098-728-34-83. E-mail: nlevkivska@gmail.com, bvh@ukr.net
Levkivska, N.D., Levkivsky, D.M., \& Gutyj, B.V. (2019). Epizootic features of the manifestation of clostridiosis and means of specific prophylaxis of animals in Ltd n.a. Volovikova Hoshchansk districk, Rivne region. Scientific Messenger of Lviv National University of Veterinary Medicine and Biotechnologies. Series: Veterinary sciences, 21(94), 127-131. doi: 10.32718/nvlvet9423

According to the results of experimental and practical analysis it was determined that clostridia has an optional type of parasitism. Pathogens of clostridiosis can be stored in an abiotic environment. Under certain conditions, they multiply in soil, while reducing their virulent properties and restoring them in the process of passage through the body of susceptible animals (bones), while maintaining high virulent properties. It has been established that the epizootic process in clostridiosis is a functionally parasitic system in which the parasite populations and susceptible animals (host) interact and are provided with mechanisms for the transition of clostridia from biotic to abiotic objects (the source of the pathogen of infection, which is the cattle), calves, animal corpses, and soils) into a new facility where it changes its virulent properties and ensures the continuity of its operation. In order to specifically prevent infectious diseases of animals caused by pathogens of clostridial etiology, such as: infectious anaerobic dysentery, emphysematous carbuncle of cattle, infectious anaerobic enterotoxemia, hemorrhagic enteritis, enterotoxemia and tetanus in sub-calves, sheep, goats, lambs and goats, necrotic hepatitis Toxipra plus a vaccine that, after administration, induced the formation of an active immune response in animals before clostridios 21 days after a double intramuscular injection ovoho vaccine, immunity lasted for 12 months. To protect the organism of animals from spore-forming bacteria - clostridia, animals were subcutaneously administered an inactivated multiclus vaccine in a dose of $5.0 \mathrm{ml}$. Previously unvaccinated animals were immunized twice at intervals of 3-4 weeks. Revaccination of animals was carried out annually with one dose of the vaccine every 12 months. To ensure a satisfactory level of immune protection of the bivalve organism from clostridios, an inactivated, polyvalent Coglavax vaccine was used in compliance with the aseptic and antiseptic rules. In adult animals, the immunity was formed 2-3 weeks after re-vaccination and stored for 10-12 months. In the young, obtained from cows alone, vaccinated 2 weeks before the calf, colostrum immunity is maintained for up to 8 weeks. An Inactivated Vaccine Van Shot Ultra 8 vaccine was used to create immune protection of cattle from clostridios and pasteurellosis. Formation of immunity occurs 3 weeks after a two-time vaccination, which lasts for at least 12 months. In order to effectively predict the planning of general and special anti-echelmonial measures in animals, it is necessary to create a cadastre of dysfunctional points for diseases caused by clostridia, and to formulate strategies for the active immunization of susceptible animals.

Key words: clostridiosis, epizootic process, infectious process, specific prophylaxis, animals, infection, immunity. 


\title{
Епізоотичні особливості прояву клостридіозів та засоби специфічної профілактики тварин у ТОВ СГП імені Воловікова Гощанського району Рівненської області
}

\author{
Н.Д. Левківська, Д.М. Левківський, Б.В. Гутий
}

Львівський національний університет ветеринарної медицини та біотехнологій імені С.3. Гжицุького, м. Львів, Україна

\begin{abstract}
За результатами експериментального та практичного аналізу встановлено, щңо клостридї мають факультативний тип паразитування. Збудники клостридіозів здатні зберігатися в абіотичному середовищі. За певних умов вони розмножуються в трунті, знижуючи при иьому свої вірулентні властивості і відновлюють їх в процесі пасажування через організм сприйнятливих тварин (кістки), зберігаючи при иьому високі вірулентні властивості. Встановлено, щео епізоотичний процес при клостридіозах - це функціонально паразитарна система, в якій взаємодіють, адаптаційно змінюючись, популяиії паразита і сприйнятливих тварин (господаря) та забезпечуються механізмами переходу клостридій із біотичного до абіотичного об'єктів (джерела збудника інфекиії, яким є велика рогата худоба, телята, трупи тварин, а також трунти) в новий об'єкт, де він змінює свої вірулентні властивості та забезпечує безперервність його функиіонування. 3 метою специфічної профілактики інфекиійних хвороб тварин, викликаних збудниками клостридіозної етіології, таких як: інфекиійної анаеробної дизентерії, емфізематозного карбункулу великої рогатої худоби, інфекційної анаеробної ентеротоксемії, геморагічного ентериту, ентеротоксемії і правия у підсисних телят, овеиь, кіз, ягнят і козенят, некротичного гепатиту застосовували Токсіпра плюс вакиину, яка після введення викликала формування активної імунної відповіді у тварин до клостридіозів через 21 день після дворазового внутрішньом'язового введення вакцини, імунітет зберігався протягом 12 місяиів. Для захисту організму тварин від спороутворюючих бактерій - клостридій тваринам підшкірно вводили інактивовану вакиину Мультиклос в дозі 5,0 мл. Раніше невакиинованих тварин імунізували дворазово з інтервалом 34 тижні. Ревакиинацію тварин проводили щорічно однією дозою вакиини через кожних 12 місяців. Для забезпечення задовільного рівня імунного захисту організму великої рогатої худоби від клостридіозів із дотриманням правил асептики $і$ антисептики застосовували інактивовану полівалентну Коглавакс вакцину. У дорослих тварин імунітет формувався через 2-3 тижні після повторноі вакцинації $і$ зберігався протягом 10-12 місяиів. У молодняку, отриманого від тільних корів, вакцинованих за 2 тижні до отелу, колостральний імунітет зберігається до 8 тижнів. 3 метою утворення імунного захисту організму великої рогатої худоби від клостридіозів та пастерельозу застосовували інактивовану вакцину Ван Шот Ультра 8. Формування імунітету відбувається через 3 тижні після дворазової вакиинаиії, який зберігається не менше 12 місяиів. 3 метою ефективного прогнозування планування проведення загальних та спеціальних протиклостридіозних заходів у тварин, необхідне створення кадастру неблагополучних пунктів щодо захворювань викликаних клостридіями, та формування стратегії активної імунізації сприйнятливих тварин.
\end{abstract}

Ключові слова: клостридіози, епізоотичний процес, інфекиійний процес, специфічна профілактика, тварини, інфекиія, імуніmem.

\section{Вступ}

Проблема інфекційних хвороб, викликаних клостидіями, є досить актуальною в господарствах різної форми власності з високою концентрацією поголів'я тварин.

Широке розповсюдження збудників клостридіозних інфекцій в природі, висока стійкість їх в зовнішньому середовищі та постійна наявність сприятливих тварин становлять загрозу появи нових вогнищ захворювання. Спалахи хвороб тварин клостридіозної етіології найчастіше зустрічаються на низинних заболочених місцевостях, що має важливе значення для регіонів Полісся, зокрема господарств різної форм власності з високою концентрацією поголів'я тварин на обмеженій території. Тому, незважаючи на значні успіхи вакцинопрофілактики, розробка інших заходів щодо боротьби $з$ даними захворюваннями все ще залишається актуальною проблемою, особливо в плані удосконалення діагностики хвороб, вивчення особливостей прояву епізоотичного процесу при анаеробних інфекціях в різних природно- кліматичних зонах району.

Висока концентрація поголів'я тварин на обмеженій території обумовлює захворюваність їх, що приводить до значного вимушеного забою і загибелі тварин, недоодержання живої маси та перешкоджає по- дальшому розвитку тваринництва (Kurilenko \& Krupal'nik, 2000; Sasaki et al., 2000; Pytly \& Levkivskyi, 2013; Levkivsky et al., 2018; Shafranska et al., 2018).

Тому в тваринництві особливого значення набуває аналіз закономірностей виникнення і розвитку інфекцій, проведення експрес-методів групової діагностики щодо захворювань тварин, викликаних клостридіями, впровадженням специфічних схем профілактичних і протиепізоотичних заходів та їх ефективність.

На сьогодні відсутні вичерпні відповіді на найважливіші питання з етіології, характеристики епізоотичного процесу, оцінки імунітету, механізм та шляхи передачі збудника інфекції. Існуючі методи діагностики, заходи загальної і спеціальної профілактики потребують удосконалення.

Розв'язання вказаних питань дозволить побудувати теоретичні та практичні засади щодо профілактики інфекційного і епізоотичного процесів і забезпечать ліквідацію стаціонарності щодо інфекційних хвороб тварин, викликаних клостридіями в неблагополучних пунктах Гощанського району Рівненської області.

\section{Матеріал і методи досліджень}

Об'єктами досліджень були сільськогосподарські тварини (велика рогата худоба, нетелі, телички) різних вікових груп, матеріали облікової та ветеринарної 
звітності на базі приватного підприємства ТОВ СГП імені Воловікова та Гощанської районної державної лікарні ветеринарної медицини. Предметами досліджень були епізоотичний та інфекційні процеси хвороб тварин, викликаних клостридіями, у приватному господарстві ТОВ СГП імені Воловікова.

Методика дослідження. У роботі використано такі методи дослідження: епізоотичний, клінічний, імунологічний, бактеріологічний, порівняльногеографічний.

Дослідження проводились на базі приватного підприємства ТОВ СГП імені Воловікова Гощанського району Рівненської області. В господарстві переважна більшість корів - української чорно-рябої молочної породи. Середня продуктивність на одну корову складає 5000 кг молока на рік. Племінна робота в господарстві ведеться на належному рівні.

На даний час в структурі господарства перебуває всього: 4170 голів, (100\%), із них дійних корів - 1402 (33,6\%), нетелів - 374 (8,96\%), телички 0-2 міс. - 119 (2,85\%), телички 2-6 міс. - 500 (11,9\%), телички 6-15 міс. - 888 (21,5\%), телички 15-22 міс. - 837 (20,0\%), бички 0-2 міс. - 44 (1,05\%), ВРХ на відгодівлі - 6 $(0,14 \%)$.

У роботі також було вивчено та проаналізовано ефективність схем профілактичних та протиепізоотичних заходів щодо інфекційних хвороб тварин, запропонованих компанією "MSD Animal Health". Зокрема проведено аналіз схем імунопрофілактики тварин щодо хвороб викликаних збудниками клостридіозних інфекцій. Апробовано схеми імунопрофілактики хвороб тварин, викликаних клостридіозами, із застосуванням таких вакцин: Ван Шот Ультра 8, Токсіпра плюс, Мультиклос, а також Коглавакс. Дані вакцини рекомендовані Державною фармакологічною комісі$є ю$ ветеринарної медицини згідно з експертним висновком, наказом Державної служби України з питань безпечності харчових продуктів та захисту споживачів від 18.12.2017 року за № 1197 і зареєстровані в Україні за № ВА00858-02-17 від 18.12.2017 року.

\section{Результати та їх обговорення}

Аналіз даних ветеринарної звітності щодо інфекційних захворювань великої рогатої худоби та телят у Гощанському районі Рівненської області за останні 10 років показав, що серед інфекційної патології на хвороби тварин клостридіозної етіології припадає близько 9,0\% від усієї кількості неблагополучних пунктів, що були зареєстровані за цей період. При цьому не встановлено залежності числа хворих від кількості неблагополучних пунктів - зазвичай інфекція мала спорадичний прояв. Для механізму передачі клостридій тваринам притаманна змінність трьох фаз (стадій): виведення збудника інфекції з організму тварин; перебування його в об'єктах довкілля (грунт може виступати як джерелом збудника інфекції, так і фактором передачі) та проникнення в організм сприйнятливих тварин. Епізоотичні та експериментальні дослідження показали неконтагіозність інфекцій та особ- ливості циркуляції клостридій у популяціях в організмі клінічно здорових тварин.

Встановлено, що в стаціонарно неблагополучних щодо хвороб тварин клостридіозної етіології пунктах збудник інфекції постійно циркулює в системі: абіотичне середовище (джерело клостридій) - організм тварини - абіотичне середовище. При виникненні клінічних ознак хвороби названа система активізується за рахунок явних джерел - хворих тварин та їхніх трупів. Хвороби тварин, викликані клостридіями, мають спорадичний та ензоотичний прояв інфекції, а без медикаментозного втручання у таких тварин летальність може сягати до 98\%. Найвищий прояв захворювань припадає на два піки інцидентності (веснянолітній та осінній). Перший ми пов'язуємо з весняними та літніми повенями і зливами (вплив абіотичних факторів), другий - 3 особливістю перебігу хвороб, які розвиваються за законами імунізуючої субінфекцiï.

У динаміці епізоотичного процесу між стадіями розвитку хвороби можна виділити такі стадії: міжепізоотичну, передепізоотичну, спорадичного клінічного прояву інфекції та постепізоотичну стадії. Передепізоотична стадія клостридіозних інфекцій, на відміну від класичного епізоотичного процесу, характеризується не проявом клінічних ознак хвороб поодиноких тварин, а наявністю на території збудників клостридіозів та сприяючих етіологічних факторів (можливість травмування, інтенсивність приросту маси). Для стадії клінічного прояву інфекції характерним є спорадичність, а при масових захворюваннях тварин - відсутність ознак контагіозності. Стадія латентного перебігу захворювання проявляється такими ознаками, як наявність абіотичного джерела збудника інфекції в сприйнятливих (неімунних) тварин та тварин в стані імунізуючої субінфекції. У подальшому епізоотичний процес проявляється постійною імунізуючою субінфекцією. В такому стаді можливий прояв клінічної форми інфекції, та лише у молодих (неімунних) тварин або серед завезеної великої рогатої худоби.

Для специфічної профілактики інфекційних хвороб тварин, викликаних збудниками клостридіозної етіології, таких як: інфекційної анаеробної дизентерії, емфізематозного карбункулу великої рогатої худоби, інфекційної анаеробної ентеротоксемії, геморагічного ентериту, ентеротоксемії і правця у підсисних телят, овець, кіз, ягнят і козенят, некротичного гепатиту застосовували Токсіпра плюс вакцину.

До складу Токсіпра плюс вакцини входять такі компоненти: $\beta$ - і $\varepsilon$-токсоїди Clostridium perfringens типів B, C, і D, $\alpha$-токсоїд Clostridium novyi тип B, $\alpha$ токсоїд Clostridium septicum, анакультури Clostridium chauvoei, токсоїд Clostridium tetani. Дорослу велику рогату худобу і телят вакцинували внутрішньом'язово в дозі 4,0 мл на тварину з інтервалом 20-25 днів. Ревакцинацію тваринам проводили щорічно, одноразово в дозі 4,0 мл. Підсисних телят вакцинували внутрішньом'язово в дозі 2,0 мл з інтервалом 20-25 днів.

Вакцина Токсіпра плюс після введення викликала формування активної імунної відповіді у тварин до 
клостридіозів через 21 день після дворазового внутрішньом'язового введення вакцини, імунітет зберігався протягом 12 місяців.

3 метою захисту організму тварин від спороутворюючих бактерій клостридій (Clostridium septicum, Cl. novyi mun $B$, Cl. sordellii, $C l$. perfringens тип C та D, Cl.chauvoei, Cl.heamolyticum) тваринам підшкірно вводили інактивовану вакцину Мультиклос в дозі 5,0 мл. Раніше невакцинованих тварин імунізували дворазово з інтервалом 3-4 тижні. Ревакцинацію тварин проводили щорічно - однією дозою вакцини через кожних 12 місяців. Для створення більш напруженого колострального імунітету в новонароджених телят проводили вакцинацію корів перед кожним отеленням. Новонароджених телят вакцинували 3 3тижневого віку. Все стадо тварин вакцинували одночасно вакциною Мультиклос. Дана вакцина виготовлена із анатоксинів, отриманих із перерахованих культур клостридій із додаванням 25 мг алюмінієвих квасців як ад'юванта та 5 мг фенолу як консерванта.

Для забезпечення задовільного рівня імунного захисту організму великої рогатої худоби від клостридіозів із дотриманням правил асептики і антисептики застосовували інактивовану полівалентну Коглавакс вакцину. Дана вакцина призначена для профілактики клостридіозних інфекцій у великої рогатої худоби та овець, що спричинені Clostridium perfringens (типів А, B, C, D), Cl. septicum, Cl. novyi, Cl. tetani, Cl. chauvoei, анаеробної ентеротоксемії, токсичної ентеротоксемії (хвороба розм'якшеної нирки), геморагічного ентериту, некротичного гепатиту, брадзоту, емфізематочного карбункулу, злоякісного набряку, правця у всіх типах господарств.

Коглавакс вакцину вводили підшкірно в дозі 4,0 мл великій рогатій худобі, а також телятам масою понад 100 кг. Друге введення вакцини проводили через чотири тижні після першого введення, ревакцинацію тваринам проводили через рік після останнього введення вакцини. Телятам масою тіла до 100 кг Коглавакс вакцину вводили підшкірно в дозі 2,0 мл дворазово 3 інтервалом у 4 тижні. Ревакцинацію телят проводили в дозі 4,0 мл через рік після останнього введення вакцини. Тільним коровам Коглавакс вакцину вводили підшкірно в дозі 4,0 мл на початку 6-го місяця тільності, а друге введення в тій же дозі проводили через 4 тижні після першого введення, наприклад, на 7 - му місяці тільності корів. Ревакцинацію тільним коровам Коглавакс вакциною в дозі 4,0 мл проводили через рік після останнього введення та при можливості близько 7-го місяця тільності. У дорослих тварин імунітет формувався через 2-3 тижні після повторної вакцинації i зберігався протягом 10 12 місяців. У молодняку, отриманого від тільних корів, вакцинованих за 2 тижні до отелу, колостральний імунітет зберігається до 8 тижнів.

3 метою утворення імунного захисту організму великої рогатої худоби від клостридіозів та пастерельозу застосовували інактивовану вакцину Ван Шот Ультра 8. Дана вакцина складається з двох компонентів: бактерин-токсоїд Mannhemia (Pasteurella) haemolytica - ліофілізований компонент; токсоїд Clostridium chauvoi, Cl. septicum, Cl. novyi, Cl. sordellii, $C l$. perfringens типів $\mathrm{C} \mathrm{i} \mathrm{D}, \mathrm{Cl}$. haemolyticum - рідкий компонент, а також містить такі ад'юванти: алюмінієвий калієвий сульфат (галун), сапонін і спеціальний водорозчинний Стімуген.

Після підшкірного введення Ван Шот Ультра 8 вакцини у тварин стимулюється розвиток напруженого імунітету проти Clostridium chauvoi, Cl. septicum, $\mathrm{Cl}$. novyi, $\mathrm{Cl}$. sordellii, $\mathrm{Cl}$. perfringens типів B, C і D, Cl. haemolyticum, та пневмоніï, що викликається Mannhemia haemolytica, який формується через три тижні після двократної вакцинації і зберігається протягом не менше ніж 12-ти місяців.

Розведену ліофілізовану фракцію вакцини вводили підшкірно в дозі 2,0 мл (одна доза). Первинна вакцинація тварин проводилась двома дозами вакцини 3 проміжком 4-6 тижнів. Для захисту тварин з високим ризиком зараження $\mathrm{Cl}$. haemolyticum рекомендовано вакцинувати їх кожні 6 місяців. Ревакцинацію тварин проводили однією дозою вакцини раз на рік.

\section{Висновки}

Експериментально, практично і теоретично доведено, що клостридії мають факультативний тип паразитизму. За результатами досліджень проаналізовано частоту проникнення хвороботворних клостридій в організм сприйнятливих тварин, їхню здатність забезпечувати механізм переходу з біотичного до абіотичного об'єкта - джерела збудника інфекції та довгий час збереження у зовнішньому середовищі.

Проаналізовано ефективність профілактичних та протиепізоотичних заходів щодо клостридіозних інфекцій тварин в господарстві з великою концентрацією поголів'я тварин. Наведено результати апробації вакцин, запропонованих компанією "MSD Animal Health" щодо захисту організму тварин від бактеріальних патогенних клостридіозів. Тривалість напруженого імунітету при будь-якому введені вакцини тваринам складає від 21 дня до 12 місяців. Дослідження проводились на базі приватного господарства ТОВ СГП імені Воловікова Гощанського району Рівненської області. Для аналізу схем імунопрофілактики щодо інфекційних хвороб тварин викликаних клостридіями апробували такі вакцини: Мультиклос, Токсіпра плюс, Коглавакс, Ван Шот Ультра 8.

3 метою специфічної профілактики інфекційних хвороб тварин, викликаних збудниками клостридіозної етіології щодо інфекційної анаеробної дизентерії, геморагічного ентериту, емфізематозного карбункулу великої рогатої худоби, некротичного гепатиту, правця у телят, овець, кіз, ягнят і козенят застосовували Токсіпра плюс вакцину, яка викликала формування активної імунної відповіді у тварин до клостридіозів через 21 день після дворазового введення вакцини, імунітет зберігався до 12 місяців. Для захисту організму тварин від спороутворюючих бактерій - клостридій тваринам застосовували інактивовану вакцину Мультиклос. Ревакцинацію тварин проводили щоріч- 
но через кожних 12 місяців. Для забезпечення формування належного рівня імунного захисту організму тварин від клостридіозів застосовували інактивовану полівалентну Коглавакс вакцину. У дорослих тварин імунітет формувався через 2-3 тижні і зберігався протягом 10-12 місяців. У молодняку, отриманого від тільних корів, вакцинованих за 2 тижні до отелу, колостральний імунітет зберігався до 8 тижнів.

3 метою утворення імунного захисту тварин від клостридіозів та пастерельозу застосовували інактивовану вакцину Ван Шот Ультра 8. Формування напруженого імунітету відбувалося через 3 тижні і зберігало не менше ніж 12 місяців.

\section{References}

Kurilenko, A.N., \& Krupal'nik, V.L. (2000). Infekcionnye bolezni molodnjaka sel'skohozjajstvennyh zhivotnyh. M.: Kolos (in Russian).

Levkivsky, D.M., Levkivska, N.D., Gutyj, B.V., \& Leno, M.I. (2018). Analysis of treatment and preventive measures for infectious diseases of calves, Agricultural Enterprise "Volovikov" Ltd, Goshansky district, Rivne region. Scientific Messenger of Lviv National University of Veterinary Medicine and Biotechnologies, 20(83), 93-96. doi: 10.15421/nvlvet8318 (in Ukrainian),

Pytly, K.Z., \& Levkivskyi, D.M. (2013). Epizootolohiia emfizematoznoho karbunkulu velykoi rohatoi khudoby hospodarstv riznykh form vlasnosti IvanoFrankivskoi oblasti. Nauk. pratsi mizh nar. nauk. stud. konferentsii. Lviv, 76-77 (in Ukrainian).

Sasaki, Y., Yamamoto, K., Kojima, A., \& Tamura, Y. (2000). Rapid identification and differentiation of pathogenic clostridia in gas gangrene by polymerase chain reaction based on the $16 \mathrm{~S}-23 \mathrm{~S}$ rDNA spacer region. Res. Vet. Sci., 69, 289-294. doi: 10.1053/rvsc.2000.0431.

Shafranska, R.Yu., Kashliak, M.S., Hrabova, M.B., \& Levkivska, N.D. (2018). Epizootolohiia Emfizematoznoho karbunkulu velykoi rohatoi khudoby hospodarstv riznoi formy vlasnosti Lokachynskoho raionu Volynskoi oblasti. Zbirnyk statei mizhnarodnoi konferentsii. LNUVMBT imeni S.Z. Hzhytskoho, Lviv, 214-217 (in Ukrainian). 